\title{
POTENSI TAMARIN LOKAL SEBAGAI PENGGANTI TAMARIN KOMERSIAL DAN EMULSI PADA PENCAPAN POLIESTER
}

\section{LOCAL TAMARIND POTENTIAL AS A SUBSTITUTE FOR COMMERCIAL TAMARIND AND EMULSION IN POLYESTER PRINTING}

\author{
Ima Winaningsih, Amaliya Sita P dan Jamal Adi Prasetyo \\ Akademi Komunitas Negeri Kajen PDD Politeknik Negeri Bandung \\ Jalan Bahurekso No.1 Kajen, Kabupaten Pekalongan 51161 \\ E- mail: ima.winaningsih.pdd@ polban.ac.id
}

Tanggal diterima: 22 April 2019, direvisi: 4 Juli 2019, disetujui terbit: 12 Juli 2019

\begin{abstract}
ABSTRAK
Tepung tamarin dari biji asam jawa berpotensi sebagai pengental pada pencapan poliester, namun belum banyak digunakan. Umumnya kebutuhan pengental tamarin dipenuhi dengan impor atau digantikan dengan pengental emulsi. Penelitian ini bertujuan menganalisis karakteristik dari tepung tamarin, karakteristik dari pengental (tamarin lokal, tamarin komersial, dan emulsi) serta pengujian dan evaluasi hasil cap. Penelitian ini dimulai dengan membuat tepung tamarin (tamarin lokal), membuat pasta cap dari pengental tamarin lokal, tamarin komersial dan emulsi, kemudian melakukan proses printing dengan termofiksasi suhu $200^{\circ} \mathrm{C}$ selama 1 menit selanjutnya hasil cap dilakukan pengujian dan evaluasi. Tepung tamarin yang dihasilkan memiliki warna putih keabu - abuan, berbau khas tepung, MR 0,25\%, hasil FTIR memiliki gugus yang relatif sama dengan tamarin komersial. Hasil cap dari ketiga pengental memiliki kerataan yang baik dan warna permanen. Viskositas yang dihasilkan tamarin lokal 12.000 cPs merupakan viskositas optimum pencapan poliester. Hasil pengujian dan evaluasi ketahanan luntur warna pada pengental tamarin lokal, tamarin komersial, dan emulsi masing - masing terhadap gosokan (3-4, 4-5, 4-5), pencucian (semua 4-5), panas penyetrikaan $(5,4-5,4)$. Pada analisis ketuaan warna dan perbedaan warna dengan spektrofotometer didapatkan warna hasil cap menggunakan tamarin lokal memiliki kemiripan dengan tamarin komersial dibandingkan dengan emulsi. Warna yang dihasilkan tamarin lokal paling tua di antara ketiganya. Tepung tamarin lokal dapat dijadikan pengental tekstil pada pencapan poliester dan berpotensi sebagai bahan pengganti tamarin komersial (impor) dan pengental emulsi.
\end{abstract}

Kata Kunci: Tamarin, Emulsi, Pengental, Pencapan Poliester.

\section{ABSTRACT}

Tamarind flour from Javanese Tamarind seed has a potential as thickener for polyester printing, yet has not been widely used. Generally, tamarind thickener is imported or substituted by emulsion. This research aimed to analyze the characteristics of tamarind flour, the characteristics of thickener (local tamarind, commercial tamarind, and emulsion) and to evaluate the printing result. The research was started by making the tamarind flour (local tamarind), the printing pastes from local tamarind, commercial tamarind, and emulsion thickener, then using it for printing processing thermofixation $\left(200^{\circ} \mathrm{C}, 1\right.$ minute), and finally the result was tested and evaluated. The flour made by local tamarind has a greyness white color, flour-like smell, MR 0.25\%, and the FTIR result of local tamarind has relatively the same cluster as commercial tamarind. The printing results of the three thickeners showed an even and permanent color. The viscosity of local tamarind is $12.000 \mathrm{cPs}$; which is the optimum viscosity of polyester printing. The results of color fastness testing and evaluation of local tamarind, commercial tamarind, and emulsion thickener respectively were on rubbing (3-4, 4-5, 4-5), washing (all variables 4-5), ironing (5, 4-5, 4). Thecolor strength and color difference analysis using spectrophotometer resulted ona similar color of local tamarind printing result compared to the commercial tamarind and emulsion. The color from local tamarind was the darkest of all. Local tamarind flour can be used as textile thickener in polyester printing and has a potential for substituting the commercial (imported) tamarind and emulsion.

Keywords: Tamarind, Emulsion, Thickener, Polyester printing.

\section{PENDAHULUAN}

Indonesia merupakan negara berkembang yang memiliki berbagai jenis industri, dalam perkembangannya untuk meningkatkan daya saing antar industri satu dengan yang lain diperlukan suatu inovasi tepat guna yang dapat menekan biaya produksi. Salah satu upaya adalah dengan mengganti bahan baku impor dengan bahan baku 
lokal yang memiliki kualitas yang sama tetapi harga lebih ekonomis. Setiap daerah di Indonesia memiliki kekhasan industri masing - masing.

Kabupaten Pekalongan merupakan daerah yang memiliki unit kegiatan masyarakat (UKM) dan industri tekstil terbesar di Indonesia. Kabupaten ini terkenal dengan industri tekstil kain batik dan kain sarung yang mana dalam produksinya terdapat proses pencapan (printing). Bahan utama yang digunakan dalam pasta pencapan ini adalah pengental.

Pengental berfungsi sebagai zat pembantu untuk melekatkan zat warna pada kain sehingga menimbulkan gambar/corak/motif tertentu. Pengental dapat berasal dari alam maupun buatan. Pengental alam antara lain tapioka, tragan, terigu, gom, alginat, tamarin dan lain-lain. Pengental buatan antara lain polivinil alkohol (PVA), karboksimetil selulosa (CMC), emulsi dan lain sebagainya. ${ }^{8,14}$

Jenis pengental yang dipilih untuk pencapan harus disesuaikan dengan macam serat tekstil dan bahan yang akan dicap, jenis zat warna, dan alat/mesin yang digunakan. Pada UKM dan industri tekstil sebagian besar bahan kain yang digunakan merupakan kain poliester atau campurannya karena bahan baku ini lebih murah dan diminati konsumen. Pada umumnya, di UKM dan industri tekstil di Kabupaten Pekalongan pengental untuk pencapan poliester menggunakan pengental emulsi. Pengental emulsi adalah pengental yang terbuat dari koloid minyak dan air yang dalam penyatuannya dibantu oleh zat emulsifier. Umumnya, minyak yang sering digunakan adalah minyak tanah. Minyak tanah merupakan sumber daya alam yang tidak dapat diperbaharui, ketersediaanya mulai langka, dan harganya cukup mahal. Minyak tanah dapat merusak lingkungan karena sulit untuk diuraikan. Untuk mengatasi hal tersebut, perlu adanya inovasi pengental dari alam yang ramah lingkungan yaitu pengental tamarin yang dibuat dari biji asam jawa. Pengental ini mempunyai sifat-sifat yang baik yang memenuhi syarat pengental untuk proses pencapan bahan tekstil poliester dan sangat baik digunakan pada pencapan yang menggunakan zat warna dispersi.

Kebutuhan akan tepung tamarin untuk saat ini masih diimpor dari India, padahal Indonesia termasuk penghasil buah asam jawa (Tamarindus Indica $L$ ) terutama di daerah Madura, Mojokerto, Nusa Tenggara Barat dan Nusa Tenggara Timur ${ }^{10}$ serta menyebar di wilayah Jawa Tengah termasuk di Kabupaten Pekalongan. Jumlah asam jawa yang diimpor Indonesia pada tahun 2015 dan 2016 berturut-turut sebanyak $1.326 .240 \mathrm{~kg}$ dan 207.171 kg. Sedangkan jumlah asam jawa yang diekspor pada tahun 2015 sebanyak $19.707 .033 \mathrm{~kg}$ dan pada tahun 2016 sebanyak $14.810 .416 \mathrm{~kg} .^{3}$

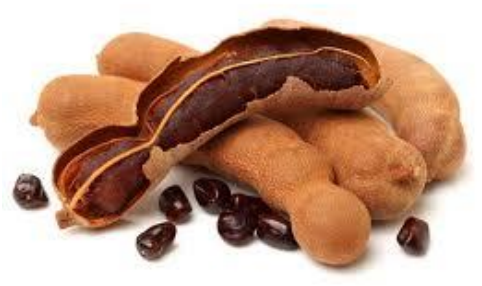

Gambar 1. Buah Asam Jawa (Tamarindus Indica L)

Pemanfaatan buah asam jawa masih terbatas untuk bumbu masakan dan obat - obatan sedangkan bijinya masih dianggap sebagai limbah. ${ }^{2}$

Pada buah asam jawa kandungan protein dan karbohidratnya merupakan yang tertinggi di antara buah-buahan lainnya. Buah yang matang terdiri dari daging buah $55 \%$, biji $33 \%$ dan serat $12 \%$. Bijinya sendiri terdiri dari $30 \%$ kulit ari dan $70 \%$ biji bagian dalam. ${ }^{1,8}$ Komposisi biji tamarin disajikan pada Tabel 1. diketahui bahwa biji tamarin mengandung sekitar $60 \%$ polisakarida. ${ }^{4}$

Tabel 1. Komposisi Biji Tamarin ${ }^{4}$

\begin{tabular}{lll}
\hline No. & Keterangan & Presentase $\mathbf{( \% )}$ \\
\hline 1. & Kelembaban & 8,1 \\
2. & Protein & 17 \\
3. & Lemak & 7 \\
4. & Polisakarida & 60,1 \\
5. & Crude fiber $\quad$ K, Ca, & 5 \\
6. & Mineral (Na, K, \\
& Mg, P, Si) \\
\hline
\end{tabular}

Polisakarida sangatlah penting bagi kebutuhan obat-obatan. Di samping itu polisakarida dari biji tamarin dapat digunakan sebagai stabilizer, pengental, dan gelling agent. ${ }^{12}$

Pada penelitian terdahulu, telah dibuktikan bahwa biji asam jawa/tamarin dari SOE-NTT yang dibuat sendiri (tamarin lokal) memiliki sifat yang hampir sama dengan tamarin impor dari India (tamarin komersial yang ada di pasaran) bahkan lebih unggul untuk ketuaan warnanya (menggunakan Zat warna C.I Disperse Yellow 144, C.I Disperse Red 73 dan C.I Disperse Blue 60), pengujian hasil cap dilakukan dengan pengujian tahan luntur warna terhadap gosokan, pencucian, keringat, dan sinar matahari. Fiksasi dilakukan dengan termofiksasi pada suhu $200^{\circ} \mathrm{C}$ dalam waktu 30 detik $^{7}$ sedangkan pada penelitian lain fiksasi dengan termofiksasi untuk pencapan poliester dilakukan pada suhu $180-210^{\circ} \mathrm{C}$ selama $120-40$ detik. ${ }^{11}$

Pada penelitian ini, dilakukan pemanfaatan biji asam jawa menjadi tepung tamarin untuk digunakan sebagai pengental pada pencapan poliester dengan mengembangkan metode penelitian sebelumnya. Pada penelitian sebelumnya, 
belum dilakukan uji karakteristik pengental (tekstur, warna, kekentalan/ viskositas, pencampuran dengan warnanya, kemudahan dalam perakelan dan kerataan hasil cap) antara tamarin lokal dibandingkan dengan pengental tamarin komersial dan pengental emulsi. Selain pengujian dan evaluasi tahan luntur warna terhadap gosokan, pencucian, perbedaan warna dengan spektrofotometer dilakukan pula evaluasi hasil pencapan dengan panas penyetrikaan. Perbedaan lainnya, penelitian ini menggunakan bahan baku biji asam asam jawa yang berasal dari wilayah Kabupaten Pekalongan, menggunakan zat warna Terasil Orange 5RL (Swisstex) dan fiksasi dilakukan dengan termofiksasi suhu $200^{\circ} \mathrm{C}$ dalam waktu 60 detik.

Pembuatan tepung tamarin dari biji asam jawa merupakan solusi dalam menangani masalah ketergantungan impor tamarin dari India dan penggunaan emulsi yang tidak ramah lingkungan serta masalah pemanfaatan biji asam yang belum optimal di Indonesia. Penelitian mengenai hal tersebut masih jarang dilakukan di Indonesia sehingga perlu adanya penelitian lanjutan.

Penelitian ini memiliki tujuan untuk mengetahui karakteristik (tekstur, rendemen, MR, dan analisa gugus fungsi) tepung tamarin yang dihasilkan (tamarin lokal) dan juga mengetahui karakteristik pengental (tekstur, warna, kekentalan/viskositas, pencampuran dengan warnanya, kemudahan dalam perakelan dan kerataan hasil cap) tamarin lokal, pengental tamarin komersial, dan pengental emulsi pada pencapan polyester. Selain itu, penelitian ini juga dilakukan untuk mengetahui hasil uji ketahanan luntur warna terhadap gosokan, pencucian, panas penyetrikaan, analisa ketuaan dan perbedaan warna dengan spektrofotometer pada termofiksasi dengan suhu $200^{\circ} \mathrm{C}$ dalam waktu 60 detik dan mengetahui potensi pengental tamarin lokal untuk menjadi pengental tekstil dalam pencapan poliester serta sebagai bahan subtitusi pengganti tamarin impor.

\section{METODE PENELITIAN Bahan dan Alat}

Bahan yang digunakan adalah screen, diazol emultion photosensible, diazol hardener, kertas kalkir, soda ash, soda kostik, teepol, biji asam jawa, tepung tamarin komersial, emulsifier merk emacol, minyak tanah, zat warna disperse terasil orange 5RL (Swisstex), kain poliester, kain katun, natrium hidrosulfit, dan aquades.

Alat yang digunakan dalam penelitian ini adalah peralatan printing, oven, panci, ayakan, blender/penggiling, timbangan analitik, mixer, hair dryer, pengaduk, Fourier Transform Infra Red (FTIR), termometer, $\mathrm{pH}$ meter, viscometer RION VT, spektrofotometer, crockmeter, launderometer, dan peralatan gelas.
Penelitian dilakukan di Laboratoriun Teknik Kimia AKN Kajen PDD POLBAN, pengujian tekstil di Laboratorium Balai Besar Tekstil Bandung, dan pengujian gugus fungsi (FTIR) di Laboratorium FMIPA UM Malang.

\section{Prosedur Penelitian}

Penelitian dilakukan sesuai tahapan proses yang disajikan pada Gambar 2, meliputi persiapan awal (pembuatan motif pada screen dan scouring kain) pembuatan tepung tamarin (tamarin lokal), pembuatan pengental dan pasta cap dari tamarin lokal, tamarin komersial dan emulsi, proses pencapan poliester terakhir adalah pengujian dan evaluasi tekstil.

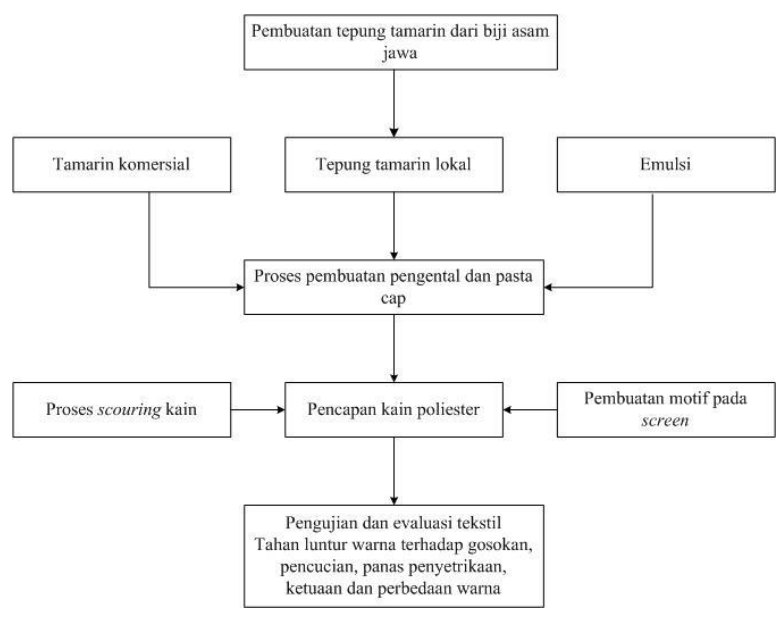

Gambar 2. Skema Penelitian

\section{Persiapan Awal}

Persiapan awal dilakukan dengan pembuatan motif pada kasa datar dengan larutan zat peka cahaya. Kain poliester yang digunakan di-scouring terlebih dahulu dengan soda ash $2 \mathrm{gr} / \mathrm{L}$, teepol $1 \mathrm{~mL} / \mathrm{L}$ selama 30 menit pada suhu $80^{\circ} \mathrm{C}$ agar kotoran pada bahan hilang dan menambah daya serap kain terhadap zat warna. ${ }^{11}$

\section{Pembuatan Tepung Tamarin}

Didahului dengan menyortir atau menyeleksi biji asam jawa, dipilih biji asam jawa yang kualitasnya bagus dan berukuran sama, tidak cacat, selanjutnya direndam $2-3$ hari agar biji yang muda bisa terlihat berbeda. Setelah direndam, biji ditiriskan agar mengurangi kadar air untuk disangrai dan kemudian dikelupas kulitnya. Tahap berikutnya adalah dioven dengan suhu $110^{\circ} \mathrm{C}$ selama 3 jam, ${ }^{8}$ lalu terakhir dilakukan penggilingan dan agar tepung lebih bersih dilakukan penyaringan. ${ }^{2,7}$

\section{Proses Pencapan Poliester dengan Termofiksasi}

Pada penelitian ini, pencapan poliester menggunakan pengental tamarin lokal dan pembanding (tamarin komersial dan emulsi) dibuat dalam resep dan kondisi yang sama yaitu pengental 
(konsentrasi 10\%), zat warna dispersi Terasil Orange 5RL 2\%, dan asam sitrat agar pH menjadi 45.

Pencapan dilakukan dengan perakelan sebanyak 2 kali, kemudian dikeringkan pada suhu $100^{\circ} \mathrm{C}$ selama 1 menit untuk menghilangkan kadar air dan difiksasi pada $200^{\circ} \mathrm{C}$ selama 60 detik. Terakhir kain hasil pencapan dicuci reduksi dengan Teepol $2 \mathrm{~mL} / \mathrm{L}$ dan natrium hidrosulfit $2 \mathrm{~g} / \mathrm{L}$ pada suhu $80^{\circ} \mathrm{C}$ selama 10 menit, kemudian dibilas sampai bersih.

\section{Pengujian dan Evaluasi Tekstil}

Pengujian dan evaluasi tekstil sangat diperlukan untuk mengetahui kualitas hasil cap. Pada penelitian ini, sampel uji pengental tamarin lokal dan pembandingnya (tamarin komersial dan emulsi) diji ketahan luntur warna terhadap gosokan kering dan basah (rubbing fastness) SNI ISO 105X12:2012, pencucian (washing fastness) SNI ISO 105-C06:2010 A2S, panas penyetrikaan (sublimasi) ISO 105-XII:1994, dan analisa ketuaan warna dan perbedaan warna SNI ISO 105-J03:2015 D65/10 .

\section{HASIL DAN PEMBAHASAN \\ Karakteristik Tepung Tamarin}

Tepung tamarin (tamarin lokal) dibuat dari biji asam jawa yang berasal dari daerah lokal (Pekalongan dan sekitarnya) dan untuk tamarin komersial adalah tamarin yang umum digunakan pada industri tekstil di Pekalongan yang diimpor dari India. Tepung tamarin hasil percobaan memiliki rendemen sekitar $32 \%$ atau dapat dikatakan dari $1 \mathrm{~kg}$ biji asam segar akan dihasilkan tepung tamarin sekitar 320 gram, nilai ini lebih kecil dari penelitian terdahulu ${ }^{7}$ (rendemen $45 \%$ ), dan memiliki kandungan air (MR) 0,25\%, lebih kecil dibandingkan dari penelitian sebelumnya ${ }^{8}$ yaitu $2,81 \%$. Hal ini dikarenakan kualitas biji asam yang diperoleh berkualitas jelek, sebagian masih muda, dan terdapat ulat. Kualitas bahan baku mempengarui kualitas tepung yang dihasilkan. ${ }^{7}$ Karakteristik untuk kedua tepung dapat dilihat pada Tabel 2.

Tabel 2. Karakteristik tepung tamarin lokal dan tamarin komersial

\begin{tabular}{llcc}
\hline \multirow{2}{*}{ No. Karakteristik } & \multicolumn{2}{c}{ Tamarin } \\
\cline { 2 - 4 } & & Lokal & Komersial \\
\hline 1. & Warna & Tepung & Kuning gading \\
2. & Bau & Halus & Obat \\
3. & Tekstur (ukuran 100 mesh) & $0,25 \%$ & Halus \\
4. & Kendungan air (MR) & C-H Alkana, C=C Alkuna, & C-H Alkana, C=C Alkuna, \\
5. & Gugus fungsi (FTIR) & C=O Alkdehid/keton/asam & C=O Alkdehid/keton/asam \\
& & karboksilat/Ester, C - H cincin & karboksilat/ Ester, C - H \\
& & aromatic, C - H Alkena, dan C & cincin aromatic, C - H Alkena, \\
& & - O Alkohol/eter/asam & dan C - O Alkohol/eter/asam \\
& & karboksilat/ester. & karboksilat/ester. \\
\hline
\end{tabular}

Tamarin lokal dan tamarin komersial memiliki warna dan bau yang berbeda, tepung tamarin lokal berwarna putih keabu - abuan, berbau tepung pada umumnya, sedangkan tamarin komersial berwarna kuning gading berbau obat, hal ini dapat terjadi karena proses pengolahan dan pengawetan. Tamarin lokal dibuat dengan proses manual dan peralatan sederhana, tanpa diberi pengawet. Proses pemasakan (penyangraian) yang terlalu sebentar akan menyulitkan proses pengelupasan kulit biji asam, sedangkan jika terlalu lama membuat biji asam gosong dan tepung yang dihasilkan berwarna coklat. Tepung tamarin lokal tanpa pengawet dapat bertahan selama tiga bulan, sedangkan untuk tamarin komersial tahan hingga dua tahun bahkan lebih pada kondisi kering dan suhu ruang.

Tepung ukuran 100 mesh baik tamarin lokal dan tamarin komersial memiliki tekstur yang sama, halus dan ringan. Ukuran yang halus membuat tepung mudah mengembang dalam pembuatan pengental. Tepung tamarin hasil percobaan dan tamarin komersial dapat dilihat pada Gambar 3.

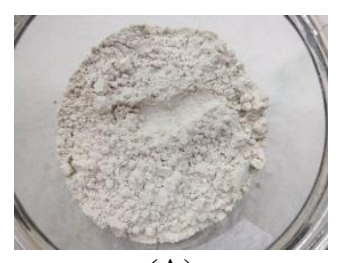

(A)

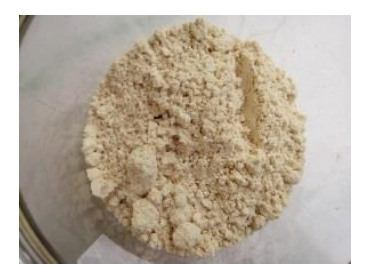

(B)
Gambar 3. Tepung tamarin lokal (A) dan tepung tamarin komersial (B)

Pada tepung tamarin hasil percobaan dengan tamarin komersial (pembanding) dilakukan analisis 
gugus fungsi menggunakan Fourier Transform Infra Red (FTIR).Gambar 4 menunjukkan bahwa kedua tepung memiliki gugus fungsi yang relatif sama, dimana pada gambar tersebut diketahui bahwa kedua tepung memiliki serapan pada panjang gelombang yang relatif sama, yaitu mengandung gugus C-H alkana $(2850-2970 \&$ $\left.1340-1470 \mathrm{~cm}^{-1}\right)$, gugus $\mathrm{C}=\mathrm{C}$ alkuna $(2100-2260$ $\left.\mathrm{cm}^{-1}\right)$ gugus $\mathrm{C}=\mathrm{O} \quad$ aldehid/keton/asam karboksilat/ester $\left(1690-1760 \mathrm{~cm}^{-1}\right)$, gugus $\mathrm{C}-\mathrm{H}$ cincin aromatik $\left(690-900 \& 3010-3100 \mathrm{~cm}^{-1}\right)$, gugus $\mathrm{C}-\mathrm{H}$ alkena $\left(675-995 \& 3010-3095 \mathrm{~cm}^{-1}\right.$ ), dan gugus $\mathrm{C}-\mathrm{O}$ alkohol/eter/ asam karboksilat/ester $\left(1050-1300 \mathrm{~cm}^{-1}\right)$, sehingga dapat dikatakan bahwa kedua tepung tersebut memiliki kandungan senyawa organik yang relatif sama pula. Adanya gugus - gugus tersebut membuat tepung tamarin dapat berikatan dengan zat warna.

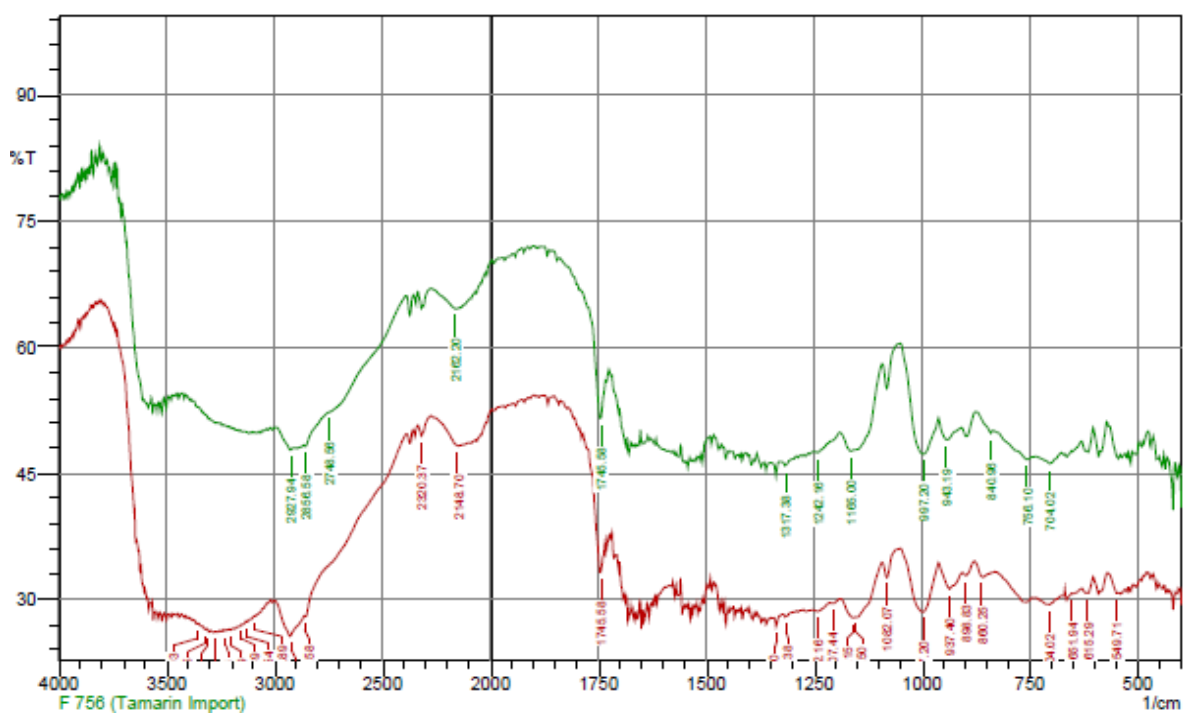

Gambar 4. Hasil analisis gugus fungsi tamarin lokal dan komersial

\section{Karakteristik Pengental}

Pengental merupakan medium untuk membawa zat warna masuk ke kain. Pada penelitian ini dilakukan perbandingan antara pengental dari tamarin lokal dengan pengental dari tamarin komersial dan pengental emulsi. Karekteristik masing - masing pengental diperlihatkan pada Tabel 3.

Tabel 3. Karakteristik pengental tamarin lokal, tamarin komersial dan emulsi

\begin{tabular}{llll}
\hline \multirow{2}{*}{ Karakteristik } & \multicolumn{3}{c}{ Jenis Pengental } \\
\cline { 2 - 4 } Tekstur & $\begin{array}{l}\text { Kental, sedikit } \\
\text { lengket }\end{array}$ & Kental, lengket & Kental tidak lengket \\
\hline Bau & $\begin{array}{l}\text { Berbau seperti } \\
\text { tepung/ bubur }\end{array}$ & Berbau seperti obat & Berbau minyak tanah \\
\hline Warna & Putih keabu - abuan & Kuning gading & Putih susu \\
\hline $\begin{array}{l}\text { Pencampuran } \\
\text { dengan warna }\end{array}$ & $\begin{array}{l}\text { Tercampur dengan } \\
\text { baik }\end{array}$ & $\begin{array}{l}\text { Tercampur dengan } \\
\text { baik }\end{array}$ & $\begin{array}{l}\text { Tercampur dengan } \\
\text { baik, }\end{array}$ \\
\hline Viskositas & $12.000 \mathrm{cPs}$ & warna lebih muda \\
\hline $\begin{array}{l}\text { Kemudahan dalam } \\
\text { perakelan }\end{array}$ & Sedang & Susah & 7.500 cPs \\
\hline Kerataan hasil cap & Rata & Rata & Mudah \\
\hline
\end{tabular}

Warna yang dihasilkan pada pengental tamarin lokal yaitu putih keabu - abuan, sedangkan pengental tamarin komersial berwarna kuning gading, dan pengental emulsi berwarna putih susu.
Ketiga pengental bercampur rata dengan zat warna dan menghasilkan warna cokelat kemerahan. Zat warna dispersi memiliki molekul yang besar dan tidak larut dalam air, warna asli zat warna hasil 
pencapan dapat dilihat setelah proses fiksasi pada suhu tinggi dan $\mathrm{pH}$ asam. ${ }^{11}$ Pada pengental tamarin warna pasta cap relatif sama, sedangkan pada pengental emulsi pasta cap berwarna cokelat lebih muda dibandingkan keduanya, perbedaan warna pasta cap tersebut dapat dilihat pada Gambar 5.

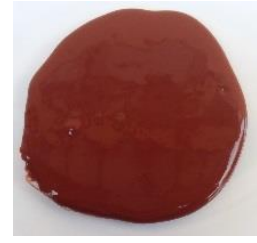

(A)

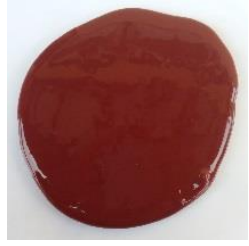

(B)

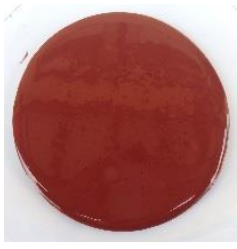

(C)
Gambar 5. Pasta cap tamarin lokal (A), Pasta cap tamarin komersial (B), dan pasta cap emulsi (C)

Viskositas antara ketiga pengental berbeda pada konsentrasi $10 \%$ didapatkan viskositas tamarin lokal sebesar $12.000 \mathrm{cPs}$, tamarin komersial 20.000 cPs, dan emulsi 7.500 cPs. Tamarin lokal memiliki viskositas yang optimal untuk pencapan poliester.
Viskositas yang sesuai untuk pencapan poliester sebesar \pm 12.000 cPs. $^{7}$ Viskositas mempengaruhi proses pada perakelan dan hasil cap yang dihasilkan. Terlalu encer mengakibatkan pasta cap keluar motif (blobor/bleeding), sedangkan pasta cap yang terlalu kental mengakibatkan proses perakelan yang susah sehingga zat warna hanya menempel pada permukaan saja. ${ }^{9}$ Hal ini mengakibatkan kurang maksimalnya proses fiksasi sehingga dapat mengakibatkan luntur warna ketika pencucian. ${ }^{9}$

\section{Kain Hasil Pencapan Poliester}

Kain hasil pencapan memiliki kerataan motif yang baik, handfeel yang lembut, warna yang tajam dan permanen, tetapi setiap pengental memiliki perbedaan warna. Dengan tamarin lokal dihasilkan warna orange kemerahan yang lebih tua dibandingkan tamarin komersial, sedangkan emulsi menghasilkan warna orange paling muda diantara ketiganya, namun pada kain hasil cap terdapat shadow dari kain lainnya. Hal ini terjadi pada proses fiksasi. Hasil cap dapat dilihat pada Gambar 6-8.

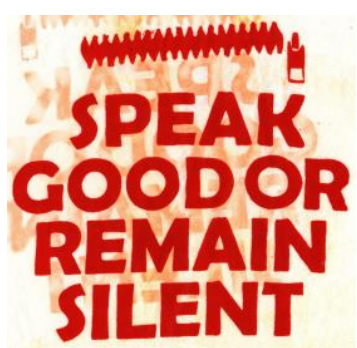

Tamarin lokal 2

Gambar 6. Hasil pencapan tamarin lokal

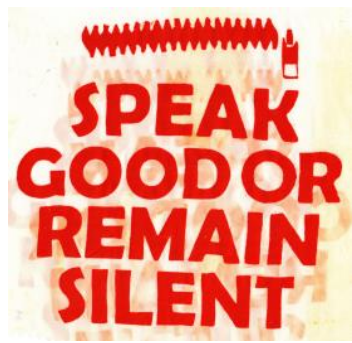

Tamarin komersial 1

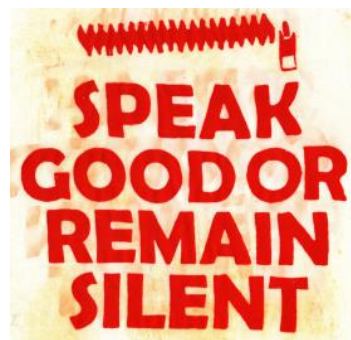

Tamarin komersial 2

Gambar 7. Hasil pencapan tamarin komersial

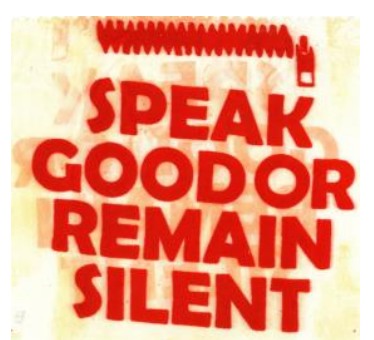

Emulsi 1

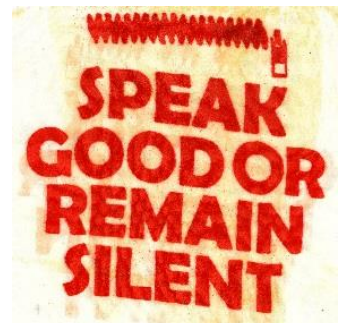

Emulsi 2

Gambar 8. Hasil pencapan emulsi 
Pada proses fiksasi terjadi ikatan zat warna ke dalam serat. Zat warna dispersi akan teraktivasi pada suhu tinggi, zat warna tersebut mudah bermigrasi (over sublimasi) sehingga membuat zat warna keluar motif/menembus dan menodai kain (shadow) di bawahnya. Untuk menanggulanginya, harus ditambahkan zat anti migran. ${ }^{5}$

Tabel 4. Hasil ketahanan luntur warna terhadap gosokan

\begin{tabular}{ccccccc}
\hline $\begin{array}{c}\text { Ketahanan luntur } \\
\text { warna terhadap } \\
\text { gosokan }\end{array}$ & Emulsi 1 & Emulsi 2 & $\begin{array}{c}\text { Tamarin } \\
\text { komersial 1 }\end{array}$ & $\begin{array}{c}\text { Tamarin } \\
\text { komersial 2 }\end{array}$ & $\begin{array}{c}\text { Tamarin } \\
\text { lokal 1 }\end{array}$ & $\begin{array}{c}\text { Tamarin } \\
\text { lokal 2 }\end{array}$ \\
\cline { 2 - 7 } & 4 & 4 & $4-5$ & 4 & $4-5$ & 4 \\
Kering & $4-5$ & $4-5$ & $4-5$ & $4-5$ & $3-4$ & $3-4$ \\
Basah & & & & & & \\
\hline
\end{tabular}

Keterangan nilai Staining Scale:

Nilai 3-4 = cukup baik

Nilai $4=$ baik

Nilai $4-5=$ baik

Nilai $5=$ sangat baik

\section{Pengujian Tahan Luntur Warna}

Pada Tabel 4, ketahanan luntur warna dari semua hasil evaluasi ketahanan luntur warna terhadap gosokan kering maupun basah pada hasil cap menggunakan pengental emulsi dan tamarin komersial memiliki nilai yang baik (4 hingga 4-5). Pada tamarin lokal, untuk gosokan kering memiliki nilai baik (4 hingga 4-5), tetapi pada gosokan basah memiliki nilai cukup baik (3-4). Penurunan nilai ini terjadi akibat zat warna yang menempel pada permukaan kain belum terfiksasi dan belum hilang dari proses pencucian. Zat warna ini memiliki ikatan yang lemah sehingga akan mudah lepas karena adanya gosokan basah. ${ }^{9}$

Tabel 5. Hasil ketahanan luntur warna terhadap pencucian

\begin{tabular}{|c|c|c|c|c|c|c|}
\hline \multirow{2}{*}{$\begin{array}{l}\text { Ketahanan Luntur } \\
\text { Warna terhadap } \\
\text { Pencucian }\end{array}$} & \multicolumn{6}{|c|}{ Hasil Uji } \\
\hline & Emulsi 1 & Emulsi 2 & $\begin{array}{c}\text { Tamarin } \\
\text { Komersial } 1\end{array}$ & $\begin{array}{c}\text { Tamarin } \\
\text { Komersial } 2\end{array}$ & $\begin{array}{l}\text { Tamarin } \\
\text { Lokal } 1\end{array}$ & $\begin{array}{l}\text { Tamarin } \\
\text { Lokal } 2\end{array}$ \\
\hline Perubahan warna & $4-5$ & $4-5$ & $4-5$ & $4-5$ & $4-5$ & $4-5$ \\
\hline $\begin{array}{l}\text { Penodaan pada } \\
\text { poliester }\end{array}$ & $4-5$ & $4-5$ & $4-5$ & $4-5$ & 4-5 & $4-5$ \\
\hline $\begin{array}{l}\text { Penodaan pada } \\
\text { kapas }\end{array}$ & $4-5$ & $4-5$ & $4-5$ & $4-5$ & $4-5$ & $4-5$ \\
\hline
\end{tabular}

Keterangan nilai Grey Scale dan Staining Scale:

Nilai 3-4 = cukup baik

Nilai $4=$ baik

Nilai 4-5 = baik

Nilai $5=$ sangat baik

Tabel 5 memperlihatkan bahwa hasil cap untuk semua jenis pengental emulsi, tamarin komersial, dan tamarin lokal menunjukkan tahan luntur warna hasil pencapan pada kain poliester tersebut mempunyai nilai 4-5 skala abu-abu (Grey Scale), yang berarti mempunyai nilai tahan luntur warna terhadap pencucian yang baik.

Pengujian tahan luntur warna terhadap panas penyetrikaan sangat sesuai untuk hasil pencelupan maupun pencapan dengan zat warna dispersi, karena zat warna ini teraktivasi dengan suhu tinggi.
Pada Tabel 6, grey scale rata - rata nilai tahan luntur warna terhadap panas penyetrikaan untuk semua pengental pada suhu $110^{\circ} \mathrm{C}, 150^{\circ} \mathrm{C}$, dan suhu $200^{\circ} \mathrm{C}$ adalah baik hingga baik sekali (4 hingga 5). Namun pada suhu $200^{\circ} \mathrm{C}$, sampel uji untuk tamarin komersial dan emulsi menyusut dan meleleh. Hal ini dikarenakan pada pengental emulsi bahan pembuatnya dari minyak tanah yang mana pada suhu tinggi akan terbakar. 
Tabel 6. Hasil tahan luntur warna terhadap panas penyetrikaan dengan Grey Scale

\begin{tabular}{ccccccc}
\hline Suhu & $\begin{array}{c}\text { Tamarin } \\
\text { Lokal 1 }\end{array}$ & $\begin{array}{c}\text { Tamarin } \\
\text { Lokal 2 }\end{array}$ & $\begin{array}{c}\text { Tamarin } \\
\text { komersial 1 }\end{array}$ & $\begin{array}{c}\text { Tamarin } \\
\text { komersial 2 }\end{array}$ & Emulsi 1 & Emulsi 2 \\
\hline $110^{\circ} \mathrm{C}$ & $4-5$ & 5 & 5 & 5 & 5 & 5 \\
$150^{\circ} \mathrm{C}$ & 5 & 4 & $4-5$ & $4-5$ & $4-5$ & $4-5$ \\
$200^{\circ} \mathrm{C}$ & 5 & $4-5$ & $3-4$ & $4-5$ & 4 & 4 \\
\hline
\end{tabular}

Keterangan Nilai Grey Scale:

Nilai 3-4 = cukup baik

Nilai $4=$ baik

Nilai $4-5=$ baik

Nilai $5=$ sangat baik

\section{Analisis Ketuaan Warna dan Perbedaan Warna}

Pada CIELAB, L* menunjukkan lightness.

Nilai $+\mathrm{L}^{*}$ menunjukkan warna putih (lebih terang) dan $-\mathrm{L}^{*}$ menunjukkan warna hitam (lebih gelap). $\mathrm{C}^{*}$ adalah kroma dan $\mathrm{H}^{*}$ adalah hue, sedangkan $\mathrm{DE}^{*}$ perbedaaan warna. $^{7}$ Pada penelitian ini, dilakukan pengujian duplo dan data sampel 2 digunakan sebagai data analisis spektro karena mendekati standar.

Tabel 7. Tamarin komersial sebagai standar

\begin{tabular}{cccc}
\hline No & $\begin{array}{c}\text { Parameter } \\
\text { analisa }\end{array}$ & \multicolumn{2}{c}{ Sampel } \\
\cline { 3 - 4 } & & $\begin{array}{c}\text { Tamarin } \\
\text { lokal 1 }\end{array}$ & $\begin{array}{c}\text { Tamarin } \\
\text { lokal 2 }\end{array}$ \\
\hline 1 & $\mathrm{DE}^{*}$ & 9,93 & 5,92 \\
2 & $\mathrm{DL}^{*}$ & $-2,16 \mathrm{D}$ & $-1,02 \mathrm{D}$ \\
3 & $\mathrm{DC}^{*}$ & $-9,57 \mathrm{D}$ & $-5,78 \mathrm{D}$ \\
\hline
\end{tabular}

Tabel 8. Emulsi sebagai standar

\begin{tabular}{cccc}
\hline No & $\begin{array}{c}\text { Parameter } \\
\text { analisa }\end{array}$ & \multicolumn{2}{c}{ Sampel } \\
\cline { 3 - 4 } & & $\begin{array}{c}\text { Tamarin } \\
\text { lokal 1 }\end{array}$ & $\begin{array}{c}\text { Tamarin } \\
\text { lokal 2 }\end{array}$ \\
\hline 1 & $\mathrm{DE}^{*}$ & 11,73 & 8,75 \\
2 & $\mathrm{DL}^{*}$ & $-6.94 \mathrm{D}$ & $-5.79 \mathrm{D}$ \\
3 & $\mathrm{DC}^{*}$ & $-7.03 \mathrm{D}$ & $-3.25 \mathrm{D}$ \\
\hline
\end{tabular}

Pada Tabel 7 dan 8 menunjukkan sampel tamarin lokal 1 dan 2 dan sebagai standar adalah tamarin komersial dan emulsi. Nilai DC* menunjukkan arah cerah atau kusam dengan nilai 5,78 Duller dan -3,25 Duller maka sampel lebih kusam daripada standar. Nilai DL* menunjukkan terang dan gelap dengan nilai -1,02 Darker dan 5,79 Darker maka sampel lebih gelap dibandingkan dengan standar. Data di atas menunjukkan bahwa perbedaan warna sampel dengan tamarin komersial lebih kecil daripada dengan emulsi sehingga hasil pencapan sampel lebih mirip dengan standar tamarin komersial daripada emulsi. Warna kain hasil cap dengan tamarin lokal lebih tua dibandingkan dengan pengental tamarin komersial dan emulsi.

\section{KESIMPULAN}

1. Tepung tamarin yang dihasilkan dari penelitian ini berwarna putih keabu-abuan, halus, berbau tepung, memiliki kandungan air (MR) 0,2\%, dan memiliki gugus fungsi gugus $\mathrm{C}-\mathrm{H}$ alkana $\left(2850\right.$ - 2970 dan $\left.1340-1470 \mathrm{~cm}^{-1}\right)$, gugus $\mathrm{C}=\mathrm{C}$ alkuna $\left(2100-2260 \mathrm{~cm}^{-1}\right)$, gugus $\mathrm{C}=\mathrm{O}$ aldehid/keton/asam karboksilat/ester (1690 $\left.1760 \mathrm{~cm}^{-1}\right)$, gugus $\mathrm{C}-\mathrm{H}$ cincin aromatik $(690$ - 900 dan $3010-3100 \mathrm{~cm}^{-1}$ ), gugus $\mathrm{C}-\mathrm{H}$ alkena $\left(675-995\right.$ dan $\left.3010-3095 \mathrm{~cm}^{-1}\right)$, dan gugus $\mathrm{C}-\mathrm{O}$ alkohol/eter/asam karboksilat/ester $\left(1050-1300 \mathrm{~cm}^{-1}\right)$ yang relatif sama dengan tamarin komersial.

2. Pengental tamarin lokal, tamarin komersial, dan pengental emulsi memiliki karakteristik yang berbeda untuk tekstur, warna, bau, dan viskositas pada kosentrasi yang sama, namun ketiganya bercampur dengan baik terhadap zat warna dispersi, hasil cap memiliki kerataan yang baik dan bersifat permanen. Pengental tamarin lokal memiliki viskositas $12.000 \mathrm{cPs}$, viskositas optimum untuk pencapan poliester sedangkan pengental tamarin komersial sebesar $20.000 \mathrm{cPs}$, dan pengental emulsi sebesar 7.500 cPs.

3. Pengujian dan evaluasi tekstil pada pengental tamarin dibandingkan dengan pengental tamarin komersial dan pengental emulsi memiliki nilai relatif yang sama, untuk ketahanan luntur warna terhadap gosokan bernilai cukup baik hingga baik (3-4, 4-5, 4-5), ketahanan luntur warna terhadap pencucian baik (4-5). Pada ketahanan luntur warna terhadap panas penyetrikaan, tamarin lokal lebih unggul dibanding kedua pengental lainnya, pada suhu $200^{\circ} \mathrm{C}$ hasil cap dengan pengental tamarin lokal memiliki nilai yang baik (4), tetapi untuk tamarin komersial dan emulsi memiliki nilai cukup baik (3 hingga 34). Hal ini dikarenakan sampel uji pada keduanya menyusut dan meleleh. Pada analisis ketuaan warna dan perbedaan warna dengan spektrofotometer didapatkan warna hasil cap menggunakan tamarin lokal memiliki kemiripan dengan tamarin komersial 
dibandingkan dengan emulsi. Warna yang dihasilkan tamarin lokal paling tua di antara ketiganya. Tepung tamarin lokal dapat dijadikan pengental tekstil pada pencapan poliester dan berpotensi sebagai bahan subtitusi/penganti tamarin komersial (impor) dan pengental emulsi.

\section{UCAPAN TERIMA KASIH}

Ucapan terima kasih disampaikan kepada DIPA POLITEKNIK NEGERI BANDUNG yang telah memberikan dana kegiatan penelitian dengan surat perjanjian pelaksanaan penelitian pemula Nomor 453.13/PL1.R7/LT/2018 tahun 2018.

\section{PUSTAKA}

1. Anonim. Tamarin (sampalok) Fruit Processing. (online). http// Tamarind ltamarinsampalok-fruitprocessing, diakses 5 maret 2018. (2006).

2. Anonim. Biji Asam Dikembangkan Menjadi Pengental Tekstil. (online). (online). http://news.liputan6.com/read/185250/bijiasam-dikembangkan-menjadi-pengental-tekstil, diakses 28 Februari 2018. (2007).

3. Badan Pusat Statistik. Indikator Pertanian Agricultural Indicator 2015/2016. Katalog 5102001. Jakarta. (2016).

4. Gursharan, Kaul, et. aI. Tamarin Date of India. Punjab: Science Tech. Entrepreneur. (2006).

5. Kumar, Candini.S. dan Bhattacharya, Sila. Tamarind Seed: Properties, Processing and Utilization. Grain Science and Technology Departement, Central Food Technological Research Institute, Mysore. (2008).
6. Mayasari, V. Pengaruh Anti Migran Terhadap Hasil Pencapan Poliester. Tugas Akhir Belum dipublikasikan Bandung: Politeknik Negeri Bandung. (2017).

7. Minolta, Konica. Komunikasi warna presisi "control warna dari persepsi ke instrument". (online).

http:/konicaminolta.com/instruments/about/net work, diakses 9 November 2018. (2016).

8. Mutia, T. Optimasi Penggunaan Tamarin Lokal pada Pencapan Poliester. Arena Tekstil, 24(2), 60-112 (2009)

9. Rao, Saideswara Y. dan Mathew, Mary K. Tamarind. Indian Cardamom Research Institute. (2005).

10. Rosyida, A \& Achadi, Didik. Pemanfaatan Daun Jati Muda Untuk Pewarnaan Kain Kapas Pada Suhu Kamar. Arena Tekstil, 29(2), 60112 (2009).

11. Soebagio, S. B., Soares, J. S., Indraswati, N \& Kurniawan, Y. Ekstraksi Polisakarida Pada Biji Tamarind (Tamarindus Indica L). Widya Teknik, 14(2), ISSN 1412-7350 (2014).

12. Sunarto. Teknik Pencelupan dan Pencapan, 3 . Jakarta. Direktorat Pembinaan Sekolah Menengah Kejuruan. (2008).

13. V.Gupta, R. Puri, S.Gupta, S.Jain, G.K.Rao. Tamarind Kernel Gum An Upcoming Natural Polysaccharide. Al-ameen College of PHarmacy Bangalore, India. (2009). 
Arena Tekstil Vol. 34 No. 1, 2019: 15-24 